\title{
RADIOCARBON AGE OFFSETS BETWEEN LIVING ORGANISMS FROM THE MARINE AND CONTINENTAL RESERVOIR IN COASTAL LOCALITIES OF PATAGONIA (ARGENTINA)
}

\author{
Roberto R Cordero ${ }^{1,2} \bullet$ Héctor Panarello $^{1} \bullet$ Sonia Lanzelotti ${ }^{3} \bullet$ Cristian M Favier Dubois $^{4}$ \\ ABSTRACT. The radiocarbon of the local reservoir effect (RE) was observed in many sectors along the Argentinean Patag- \\ onic coast. Results show variations in the ${ }^{14} \mathrm{C}$ offsets and differences between marine and continental species growing within \\ the same locality, ranging from about $80-1100 \mathrm{yr}$ BP. It is postulated that such variations are mainly due to local factors, \\ including the coast morphology and the contribution of continental waters. The relevance of these kinds of studies for the \\ interpretation of age in archaeological samples is highlighted in this paper.
}

\section{INTRODUCTION}

A conventional radiocarbon age is determined in relation to the concentration of ${ }^{14} \mathrm{C}$ found in the sample analyzed and of the atmospheric carbon dioxide with which it is in equilibrium (atmospheric carbon reservoir) (Stuiver and Polach 1977; Stuiver 1978). The difference between the sample and "modern" activity makes it possible to assign an absolute age to the sample. However, the sample may not be in equilibrium with the atmospheric reservoir, but with other carbon reservoirs (seawater, rivers, lakes, estuaries, etc.) where the ${ }^{14} \mathrm{C}$ concentration is different, originating what is called the reservoir effect (RE). These reservoirs are usually depleted in ${ }^{14} \mathrm{C}$, thus, they present older apparent ages. For instance, carbon inorganic species dissolved in seawaters globally present a ${ }^{14} \mathrm{C}$ concentration of about $400 \mathrm{yr}$ in samples in equilibrium with surface waters up to $80 \mathrm{~m}$ deep for the Northern Hemisphere (Bard et al. 1993; Stuiver and Brazionas 1993). This value has regional variations. The specific age determined has several possible causes:

1. Variations in the emergence of older, deep waters or "upwelling" (Robinson and Trimble 1981);

2. The contribution of continental waters in coastal regions;

3. The geometry of the basin (communication with the open sea);

4. The presence of rocks or fossils that contribute non-active ${ }^{14} \mathrm{C}$ carbonates or carbonates with an activity different from the sea reservoir.

All these processes affect the composition of the exoskeletons of some organisms (mollusks, crustaceans, algae, coral, fishes, sea mammals, etc.) or the composition of sea sediments, mirroring the carbon isotopic relations of this reservoir.

In coastal archaeological sites, remains from sea organisms are abundant and can show this phenomenon to a greater or lesser extent. When corrections by the $\mathrm{RE}$ are reported in ${ }^{14} \mathrm{C}$ age records, they are estimated based on calibration programs because it is still not possible to consider local variations. This makes it necessary to focus all efforts towards a regional calibration (Albero et al. 1986, 1987; Figini 1999). Although this effect is correctly characterized in many coastal areas (e.g. Dye 1994; Ingram and Southon 1996), there is little information for the vast coast of Tierra del Fuego and Patagonia. For the Beagle Channel (Tierra del Fuego), there are estimations based on archaeological

\footnotetext{
${ }^{1}$ Instituto de Geocronología y Geología Isotópica (INGEIS-CONICET), Pabellón INGEIS, Ciudad Universitaria. (1428) Buenos Aires, Argentina.

2Corresponding author. Email: 221059@ingeis.uba.ar or hector@ingeis.uba.ar.

${ }^{3}$ Facultad de Filosofía y Letras, Universidad de Buenos Aires. Puán 480 (1406) Buenos Aires, Argentina. Email: sonia_lanzelotti@hotmail.com.

${ }^{4}$ CONICET, INCUAPA, Departamento de Arqueología, Universidad Nacional del Centro de la Prov. de Buenos Aires, Av del Valle 5737 (7400) Olavarría, Argentina. Email: cfavier@coopenet.com.ar.
} 
sites of $620 \pm 140 \mathrm{yr}$ (Albero et al. 1986), in reference to an average between different sea species, and of $556 \pm 61 \mathrm{yr}$ (Albero et al. 1987) for Mytilus (mussel). The latter is used as a correction for ${ }^{14} \mathrm{C}$ ages of sea organisms found in prehistoric settlements (middens) in the area. This contribution presents estimations for modern ${ }^{14} \mathrm{C}$ age offsets obtained in 20 localities of the Fuego-Patagonic coast and 1 value from the Antarctic sector.

Some advantages for calculating the ${ }^{14} \mathrm{C}$ age offsets on modern samples are the possibility to assure the contemporaneity between them (often difficult in archaeological contexts) and omitting the problems originated by the postdepositional contamination of the sample (either pedogenic or diagenic), a factor that may introduce some complex variations.

In this work, we do not attempt to calculate the modern RE. The RE formerly estimated at $40 \mathrm{yr}$ for the Southern Hemisphere has shown significant differences in calculations made for southern Chile, New Zealand, and Tasmania by Stuiver et al (1998). This introduces an important ambiguity when calculating calibrated ages. Thus, here we present the differences in the ${ }^{14} \mathrm{C}$ ages of species in equilibrium with the marine and atmospheric reservoirs belonging to the same localities $\left({ }^{14} \mathrm{C}\right.$ age offsets). With these data, it will be possible to estimate the local RE in the future.

The calculation of the past local RE in relation to the modern local RE is valid if there were no significant climatic variations, either regional or local, that may have affected oceanic circulation patterns or coastal streams, among other factors. Palynological studies show minor environmental fluctuations during the last $4000 \mathrm{yr}$ BP in the region (Markgraf 1993; Mancini 1998), when the Patagonian coast acquired its modern general shape after a prolonged sea transgression (Codignotto 1996). Accordingly, the oldest archeological site known in continental Patagonia has a date of 3220 \pm 70 yr (LP-515), in the Península de Valdés (Gómez Otero 1994).

\section{MATERIALS AND METHODS}

There were 21 pairs of modern samples collected. In each pair, 1 sample represents the equilibrium with atmospheric reservoir (vegetables) and the other sample with sea reservoir (mollusks). They come from different coastal localities in Patagonia and Tierra del Fuego, as well as 1 sample from Livingston Island (Antarctic) (See Figure 1).

The ${ }^{14} \mathrm{C}$ activity of the atmospheric reservoir sample is taken as the modern activity, corresponding to $0 \mathrm{yr}$ BP (i.e. 1950). Using the ratio between the sea sample activity and the atmospheric one, an apparent age is assigned to the former. When the ${ }^{14} \mathrm{C}$ concentration is normalized to modern atmospheric value, corrections due to the bomb effect (de Vries 1958) or the Suess effect (Suess 1955) are not significant. It is not that these effects are not present, but variations in study areas are much less important in magnitude that the effect studied.

Most of the localities analyzed correspond to coastal sites with an archaeological interest. The ages were determined by the INGEIS laboratory $\left({ }^{14} \mathrm{C}\right.$ Analysis Laboratory, Buenos Aires, Argentina) according to the following established routines:

- Pretreatment of shells: washed with hot $\mathrm{H}_{2} \mathrm{O}_{2} 200$ vol., $2 \%$ of $\mathrm{HCl}$, to remove the surface layer, with a loss in weight of $20 \%$.

- Pretreatment of vegetables: washed with hot $\left(100^{\circ} \mathrm{C}\right) \mathrm{NaOH}, 2 \%$, to obtain a clean solution, then washed with $\mathrm{HCl} 5 \%\left(90^{\circ} \mathrm{C}\right)$.

The sea samples studied correspond to the following meso- and infra-littoral mollusks: Mussel (Mytilus edulis), Little Mussel (Brachidontes spp.), Cholga Mussel (Aulacomya ater), and Limpet 


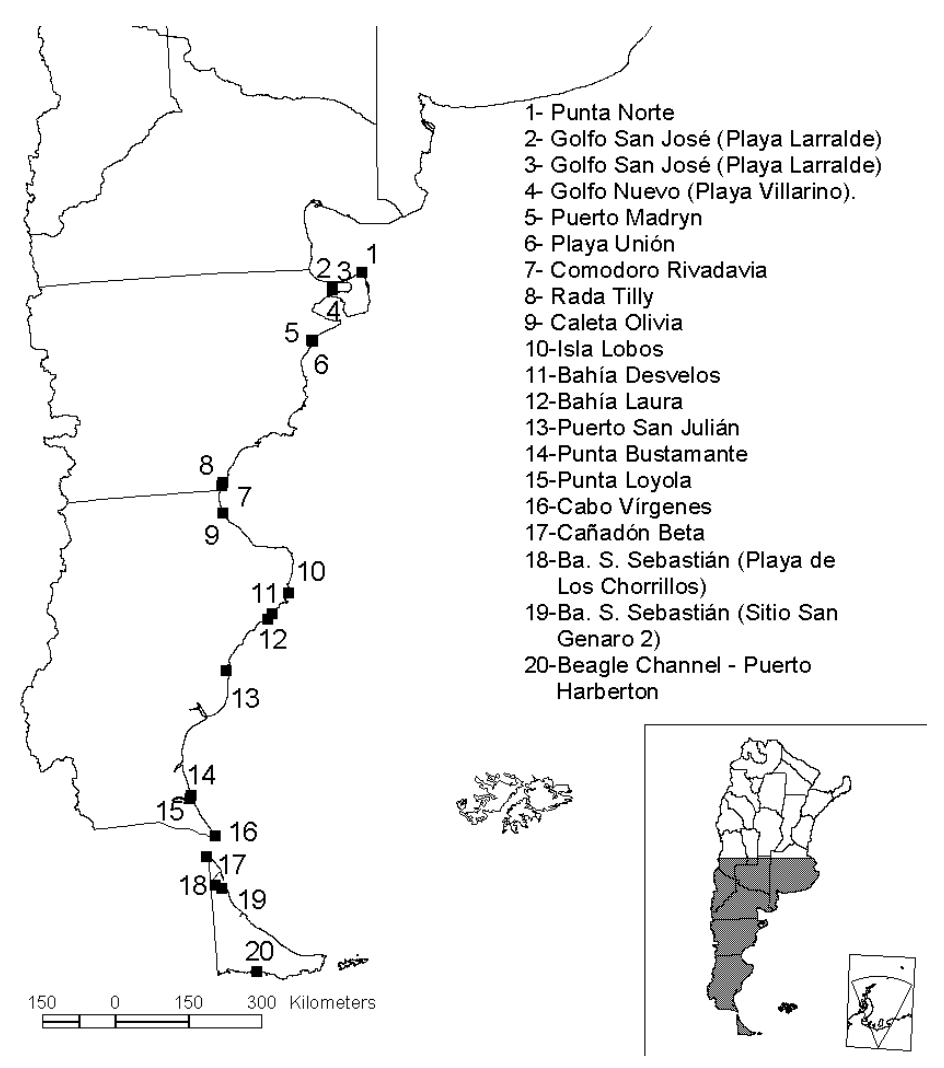

Figure 1 Coastal localities in Patagonia and Tierra del Fuego where dated samples were taken

(Patinigera sp.). They were collected in the high-tide undertow line, and appeared to be intact, bivalve species with their shells united by the ligament or, at least, with the periostracum well-preserved, so as to verify a recent death. Land samples correspond to short-life vegetal species (herbs) or young bushes' sprouts from the same localities: Coirón (Festuca sp.), Calafate (Berberis spp.), and Mata verde (Lepidophyllum cupressiforme). In the case of the Antarctic sample, it was only possible to find leaf lichens.

The ages assigned were obtained from only the sea species in each case, meaning that the interspecific variability and vital effects have not yet been considered (for the Beagle Channel, see Albero et al. 1986).

\section{RESULTS AND DISCUSSION}

One of the initial suppositions of this work was the existence of a general increase in $\Delta \mathrm{R}$ values with latitude, which is coherent with the oceanic pattern. This, however, was only suggested in open-sea localities with no influence from continental waters. As in other coastal environments, there is a very strong influence of local factors.

In the Golfo San José, the ages obtained are very old. This may be due to the abundant presence of fossil carbonates in the basin, which, together with the restricted circulation (see Figure 1), may 
Table 1 Species collected in the different localities and their ${ }^{13} \mathrm{C}$ values

\begin{tabular}{|c|c|c|c|c|c|c|}
\hline \multirow[t]{2}{*}{ Locality: } & \multicolumn{2}{|l|}{ Terrestrial } & \multicolumn{2}{|l|}{ Marine } & \multirow[b]{2}{*}{ Date } & \multirow[b]{2}{*}{ Depth [m] } \\
\hline & Genus/species & $\delta^{13} \mathrm{C}$ & Genus/species & $\delta^{13} \mathrm{C}$ & & \\
\hline 1-Punta Norte & Festuca sp. & -22.0 & Aulacomya ater & 2.0 & $01 / 28 / 99$ & 1.35 \\
\hline $\begin{array}{l}\text { 2-Golfo San José (Playa } \\
\text { Larralde), surficial water }\end{array}$ & Festuca sp. & -22.0 & $\begin{array}{l}\text { Limnoperna } \\
\text { fortunie }\end{array}$ & 2.0 & $01 / 28 / 99$ & 1.45 \\
\hline $\begin{array}{l}\text { 3-Golfo San José (Playa } \\
\text { Larralde), deep water }\end{array}$ & Festuca sp. & -22.0 & Aulacomya ater & & $02 / 08 / 00$ & 1.25 \\
\hline $\begin{array}{l}\text { 4- Golfo Nuevo (Playa } \\
\text { Villarino) }\end{array}$ & Festuca sp. & -22.0 & Aulacomya ater & 2.3 & $02 / 08 / 00$ & 1.20 \\
\hline $\begin{array}{l}\text { 5- Golfo Nuevo- } \\
\text { Puerto Madryn }\end{array}$ & Festuca sp. & -22.0 & Aulacomya ater & 1.0 & $02 / 08 / 00$ & 1.00 \\
\hline 6-Playa Unión & Festuca sp. & -22.0 & $\begin{array}{l}\text { Brachidontes } \\
\text { rodriguezi }\end{array}$ & 1.5 & $02 / 10 / 00$ & 1.17 \\
\hline 7-Comodoro Rivadavia & Festuca sp. & -28.0 & Aulacomya ater & 1.9 & $02 / 10 / 00$ & 1.26 \\
\hline 8-Rada Tilly & Festuca sp. & -25.2 & Aulacomya ater & 1.0 & $02 / 10 / 00$ & 1.35 \\
\hline 9-Caleta Olivia & Senecio sp. & -28.0 & Aulacomya ater & -9.1 & $02 / 10 / 00$ & 1.30 \\
\hline 10-Isla Lobos & Festuca sp. & -25.0 & Aulacomya ater & 1.0 & $02 / 29 / 00$ & 1.45 \\
\hline 11-Bahía Desvelos & Festuca sp. & -25.0 & Aulacomya ater & 1.0 & $12 / 14 / 99$ & 1.25 \\
\hline 12-Bahía Laura & Festuca sp. & -25.0 & Aulacomya ater & -2.4 & $12 / 10 / 99$ & 1.35 \\
\hline 13-Puerto San Julián & Poasp. & -20.9 & Mytilus edulis & 1.1 & 03/01/00 & 1.30 \\
\hline 14-Punta Bustamante & $\begin{array}{l}\text { Lepidophyllum } \\
\text { cupressiforme }\end{array}$ & -25.8 & Mytilus edulis & 1.5 & $03 / 27 / 00$ & 1.40 \\
\hline 15-Punta Loyola & $\begin{array}{l}\text { Lepidophyllum } \\
\text { cupressiforme }\end{array}$ & -23.7 & Mytilus edulis & 1.2 & $10 / 22 / 01$ & 1.45 \\
\hline 16-Cabo Vírgenes & $\begin{array}{l}\text { Lepidophyllum } \\
\text { cupressiforme }\end{array}$ & -24.9 & Aulacomya ater & 1.8 & $10 / 26 / 01$ & 1.35 \\
\hline 17-Cañadón Beta & Festuca sp. & -24.9 & Aulacomya ater & 0.6 & 07/15/99 & 1.50 \\
\hline $\begin{array}{l}\text { 18-Bahía San Sebastián } \\
\text { (Playa de Los Chorrillos) }\end{array}$ & Berberis sp. & -25.0 & Mytilus edulis & 1.1 & 07/17/99 & 1.35 \\
\hline $\begin{array}{l}\text { 19-Bahía San Sebastián } \\
\text { (Sitio San Genaro 2) }\end{array}$ & Berberis sp. & -25.0 & Mytilus edulis & 1.1 & $07 / 21 / 99$ & 1.25 \\
\hline $\begin{array}{l}\text { 20-Beagle Channel- } \\
\text { Puerto Harberton }\end{array}$ & Berberis buxifola & -25.0 & Mytilus edulis & 10.6 & $10 / 22 / 01$ & 1.35 \\
\hline $\begin{array}{l}\text { 21-Isla Livingston } \\
\text { (Antártida) }\end{array}$ & Foliose lichens & -20.3 & Patinigera sp. & 2.0 & $12 / 28 / 98$ & 0.90 \\
\hline
\end{tabular}

explain the notorious $\Delta \mathrm{R}$ increase in this sector. In the neighboring Punta Norte, the contact with the open sea reduces this local effect, providing an age coherent with oceanic parameters.

The values for Playa Unión and Punta Loyola indicate a depressed RE despite their contact with the open sea. This may be explained by the influence of continental waters from the Chubut and Gallegos rivers, respectively, as these localities are found south of their mouths, in the direction the water is dragged by littoral drift. It is suggested that, since they present a better equilibrium with continental waters (dissolved bicarbonate of a fundamentally biogenic origin), the effect is locally diluted. 
Table 2 Preliminary results of the $\Delta \mathrm{R}$ estimation in the areas considered

\begin{tabular}{|c|c|c|c|c|}
\hline Locality & $\begin{array}{l}\text { Lat }(\mathrm{S}) \\
\text { Long }(\mathrm{W})\end{array}$ & $\Delta \mathrm{R}\left({ }^{14} \mathrm{C} \mathrm{yr}\right)$ & $\mathrm{Lab} \#$ & Observations \\
\hline 1-Punta Norte & $\begin{array}{l}42^{\circ} 12^{\prime} \\
63^{\circ} 38^{\prime}\end{array}$ & $566 \pm 80$ & $\begin{array}{l}\mathrm{AC} 1504 \\
\mathrm{AC} 1510\end{array}$ & $\mathrm{OS}^{\mathrm{a}}$ \\
\hline $\begin{array}{l}\text { 2-Golfo San José (Playa } \\
\text { Larralde), surficial water }\end{array}$ & $\begin{array}{l}42^{\circ} 20^{\prime} \\
64^{\circ} 30^{\prime}\end{array}$ & $856 \pm 105$ & $\begin{array}{l}\mathrm{AC} 1504 \\
\mathrm{AC} 1614\end{array}$ & $\begin{array}{l}\mathrm{RC}^{\mathrm{b}} \\
\mathrm{PAC}^{\mathrm{c}}\end{array}$ \\
\hline $\begin{array}{l}\text { 3-Golfo San José (Playa } \\
\text { Larralde), deep water }\end{array}$ & $\begin{array}{l}42^{\circ} 20^{\prime} \\
64^{\circ} 30^{\prime}\end{array}$ & $1120 \pm 180$ & $\begin{array}{l}\text { AC1504 } \\
\text { AC1497 }\end{array}$ & $\begin{array}{l}\mathrm{RC} \\
\mathrm{PAC}\end{array}$ \\
\hline $\begin{array}{l}\text { 4- Golfo Nuevo } \\
\text { (Playa Villarino) }\end{array}$ & $\begin{array}{l}42^{\circ} 23^{\prime} \\
64^{\circ} 30^{\prime}\end{array}$ & $210 \pm 35$ & $\begin{array}{l}\mathrm{AC} 1504 \\
\mathrm{AC} 1585\end{array}$ & $\mathrm{RC}$ \\
\hline $\begin{array}{l}\text { 5- Golfo Nuevo- } \\
\text { Puerto Madryn }\end{array}$ & $\begin{array}{l}42^{\circ} 46^{\prime} \\
65^{\circ} 02^{\prime}\end{array}$ & $260 \pm 45$ & $\begin{array}{l}\mathrm{AC} 1504 \\
\mathrm{AC} 1638\end{array}$ & $\mathrm{RC}$ \\
\hline 6-Playa Unión & $\begin{array}{l}43^{\circ} 18^{\prime} \\
65^{\circ} 03^{\prime}\end{array}$ & $230 \pm 70$ & $\begin{array}{l}\mathrm{AC} 1504 \\
\mathrm{AC} 1509\end{array}$ & OS \\
\hline 7-Comodoro Rivadavia & $\begin{array}{l}45^{\circ} 52^{\prime} \\
67^{\circ} 29^{\prime}\end{array}$ & $415 \pm 45$ & $\begin{array}{l}\mathrm{AC} 1548 \\
\mathrm{AC} 1526\end{array}$ & OS \\
\hline 8-Rada Tilly & $\begin{array}{l}55^{\circ} 56^{\prime} \\
67^{\circ} 32^{\prime}\end{array}$ & $463 \pm 55$ & $\begin{array}{l}\mathrm{AC} 1607 \\
\mathrm{AC} 1605\end{array}$ & OS \\
\hline 9-Caleta Olivia & $\begin{array}{l}46^{\circ} 26^{\prime} \\
67^{\circ} 32^{\prime}\end{array}$ & $370 \pm 65$ & $\begin{array}{l}\mathrm{AC} 1548 \\
\mathrm{AC} 1566\end{array}$ & OS \\
\hline 10-Isla Lobos & $\begin{array}{l}47^{\circ} 56^{\prime} \\
65^{\circ} 51^{\prime}\end{array}$ & $355 \pm 50$ & $\begin{array}{l}\mathrm{AC} 1606 \\
\mathrm{AC} 1639\end{array}$ & OS \\
\hline 11-Bahía Desvelos & $\begin{array}{l}48^{\circ} 19^{\prime} \\
66^{\circ} 20^{\prime}\end{array}$ & $288 \pm 48$ & $\begin{array}{l}\mathrm{AC} 1606 \\
\mathrm{AC} 1640\end{array}$ & $\mathrm{RC}$ \\
\hline 12-Bahía Laura & $\begin{array}{l}48^{\circ} 24^{\prime} \\
66^{\circ} 28^{\prime}\end{array}$ & $185 \pm 35$ & $\begin{array}{l}\mathrm{AC} 1606 \\
\mathrm{AC} 1586\end{array}$ & $\mathrm{RC}$ \\
\hline 13-Puerto San Julián & $\begin{array}{l}49^{\circ} 19^{\prime} \\
67^{\circ} 42^{\prime}\end{array}$ & $485 \pm 60$ & $\begin{array}{l}\text { AC } 1527 \\
\text { AC } 1528\end{array}$ & OS \\
\hline 14-Punta Bustamante & $\begin{array}{l}51^{\circ} 34^{\prime} \\
68^{\circ} 58^{\prime}\end{array}$ & $529 \pm 90$ & $\begin{array}{l}\text { AC1499 } \\
\text { AC1498 }\end{array}$ & OS \\
\hline 15-Punta Loyola & $\begin{array}{l}51^{\circ} 37^{\prime} \\
69^{\circ} 01^{\prime}\end{array}$ & $90 \pm 25$ & $\begin{array}{l}\text { AC } 1529 \\
\text { AC } 1530\end{array}$ & $\mathrm{CC}^{\mathrm{d}}$ \\
\hline 16-Cabo Vírgenes & $\begin{array}{l}52^{\circ} 20^{\prime} \\
68^{\circ} 21^{\prime}\end{array}$ & $516 \pm 85$ & $\begin{array}{l}\mathrm{AC} 1500 \\
\mathrm{AC} 1496\end{array}$ & OS \\
\hline 17-Cañadón Beta & $\begin{array}{l}52^{\circ} 43^{\prime} \\
68^{\circ} 40^{\prime}\end{array}$ & $555 \pm 45$ & $\begin{array}{l}\mathrm{AC} 1500 \\
\mathrm{AC} 1556\end{array}$ & OS \\
\hline $\begin{array}{l}\text { 18-Bahía San Sebastián } \\
\text { (Playa de Los Chorrillos) }\end{array}$ & $\begin{array}{l}53^{\circ} 15^{\prime} \\
68^{\circ} 28^{\prime}\end{array}$ & $80 \pm 35$ & $\begin{array}{l}\mathrm{AC} 1502 \\
\mathrm{AC} 1511\end{array}$ & $\mathrm{RC}$ \\
\hline $\begin{array}{l}\text { 19-Bahía San Sebastián } \\
\text { (Sitio San Genaro 2) }\end{array}$ & $\begin{array}{l}53^{\circ} 19^{\prime} \\
68^{\circ} 17^{\prime}\end{array}$ & $265 \pm 45$ & $\begin{array}{l}\mathrm{AC} 1502 \\
\mathrm{AC} 1565\end{array}$ & $\mathrm{RC}$ \\
\hline $\begin{array}{l}\text { 20-Beagle Channel- } \\
\text { Puerto Harberton }\end{array}$ & $\begin{array}{l}54^{\circ} 53^{\prime} \\
67^{\circ} 20^{\prime}\end{array}$ & $662 \pm 65$ & $\begin{array}{l}\mathrm{AC} 1501 \\
\mathrm{AC} 1547\end{array}$ & OS \\
\hline $\begin{array}{l}\text { 21-Isla Livingston } \\
\text { (Antártica) }\end{array}$ & $\begin{array}{l}64^{\circ} 27^{\prime} \\
61^{\circ} 37^{\prime}\end{array}$ & $1900 \pm 140$ & $\begin{array}{l}\mathrm{AC} 1507 \\
\mathrm{AC} 1505\end{array}$ & OS \\
\hline
\end{tabular}

${ }^{\mathrm{a} O S}$ : open sea

${ }^{b} \mathrm{RC}$ : restricted connection with the open sea

cPAC: presence of aged carbonates

${ }^{\mathrm{d}} \mathrm{CC}$ : continental water distribution 
In coastal entries such as Golfo Nuevo, Desvelos, and the Laura and San Sebastián bays, depressed values would indicate a more effective mixture of seawater with atmospheric $\mathrm{CO}_{2}$. Coastal geometry and the smaller depth of the water in this sector facilitate this fact.

Finally, measured values in open-sea localities record a tendency for a latitudinal increase between Comodoro Rivadavia (Chubut) and Puerto Harberton (Tierra del Fuego) according to the global oceanic pattern. The value for Livingston Island (Antarctic) is also coherent with its latitude (Omoto 1983), although we lack contextual information for a better characterization of RE in this area.

\section{SUMMARY AND CONCLUSIONS}

The correction due to the RE is standardized at $400 \mathrm{yr}$ for the global oceanic average. This correction, however, is not representative of the values corresponding to many coastal areas. The Atlantic Fuego-Patagonic coast, which is more than $3000 \mathrm{~km}$ long, presents a significant spectrum of variations in their ${ }^{14} \mathrm{C}$ age offsets.

Framed in this variability and waiting for more representative values in each locality, our present research provides information that may indicate the local values of ${ }^{14} \mathrm{C}$ age offsets compared to the global oceanic average. The range of the dispersion of values obtained for these regions, on the other hand, mirrors the limitations in the systematic use of the global sea average for archaeological samples. This emphasizes the importance of local conditions.

The determination of ${ }^{14} \mathrm{C}$ age offsets is especially useful for human occupations in the Middle and Late Holocene, where differences in centuries may be important in the interpretation of the cultural chronology. This is even more important for Patagonic archaeology, in which human populations based their economy on the hunter-gatherer lifestyle until the beginning of the 20th century.

In this area, archaeological studies have increased in the last years (Gómez Otero 1995), but in the Tierra del Fuego sector research is 3 decades old (Borrero 1994-5; Orquera and Piana 1999), which highlights the increasing importance of improving the chronological tools used.

Estimating the value of the local RE is difficult due to uncertainties in calibrating ages for the Southern Hemisphere, but the approach given by ${ }^{14} \mathrm{C}$ age offsets not only widens the possibilities of correlating or comparing sites along the coast, but also allows including in the discussion sites inside the continent, where materials available for dating are not affected by this phenomenon.

\section{ACKNOWLEDGMENTS}

We want to thank the following sample collectors: Dr Gonzalez Bonorino, Dr Alicia Castro, Dr Patricia Miretzky, Lic Flavia Marina Carballo, Sr Roberto Taylor, and students Ramiro Barberena, Atilio F J Zangrando, Graciela Flores, Vivian Arias, Leticia Raffaele, Lorena Carrera, Tirso Bourlot, Augusto Tessone, Marcia Bianchi Villelli, Javier Musali, and Luciano Paffundi.

\section{REFERENCES}

Albero M, Angiolini FE, Piana EL. 1986. Discordant ages related to reservoir effect of associated archaeologic remains from the Tunel Site, Beagle Channel, Argentine Republic. Radiocarbon 28(2A):748-53.

Albero M, Angiolini FE, Piana EL. 1987. Holocene ${ }^{14} \mathrm{C}$ reservoir effect at Beagle Channel (Tierra del Fuego, Argentina Republic). Quaternary of South America and Antartic Peninsula 5:59-71.
Bard E, Arnold M, Fairbanks RG, Hamelin B. 1993. ${ }^{230} \mathrm{Th}-{ }^{234} \mathrm{U}$ and ${ }^{14} \mathrm{C}$ ages obtained by mass spectrometry on corals. Radiocarbon 35(1):191-9.

Borrero LA. 1994-5. Arqueología de la Patagonia. Palimpsesto. Revista de Arqueología 4:9-69.

Codignotto JO. 1996. Cuaternario y Dinámica Costera. Geología y Recursos Naturales de la Plataforma Continental Argentina. In: Ramos VA, Turic MA, editors. 
XIII Congreso Geológico Argentino y III Congreso de Exploración de Hidrocarburos. Relatorio 2:17-28.

de Vries H. 1958. Atom bomb effect: variations of radiocarbon in plants, shells, and snails in the past 4 years. Science 128:250-1.

Dye T. 1994. Apparent ages of marine shells: implications for archaeological dating in Hawaii. Radiocarbon 36(1):51-7.

Figini AJ. 1999. Comparación de edades C-14 en muestras de origen marino y terrestre. Efecto de reservorio. Actas del XII Congreso Nacional de Arqueología Argentina (II):353-6.

Gómez Otero J. 1994. Reseña sobre la arqueología en la Provincia de Chubut. Guía de Campo Península Valdés y Centro Noroeste del Chubut. Séptima reunión de campo. Puerto Madryn: CADINQUA. p 2943.

Gómez Otero J. 1995. Bases para una arqueología de la Costa Patagónica Central. Arqueología 5:61-103.

Ingram BL, Southon JR. 1996. Reservoir ages in eastern Pacific coastal and estuarine waters. Radiocarbon 38(3):573-82.

Mancini MV. 1998. Vegetational changes during the Holocene in Extra-Andean Patagonia, Santa Cruz Province, Argentina. Palaeogeography, Palaeoclimatology, Palaeoecology 138:207-19.
Markgraf V. 1993. Paleoenvironments and paleoclimates in Tierra del Fuego and southernmost Patagonia, South America. Palaeogeography, Palaeoclimatology, Palaeoecology 102:53-68.

Omoto K. 1983. The problem and significance of radiocarbon geochronology in Antarctica. Camberra: Australian Academy of Science. p 450-2.

Orquera LA, Piana EL. 1999. El extremo Austral del Continente Nueva historia de la Nación Argentina. Academia Nacional de la Historia 1:233-257.

Robinson SW, Trimble D. 1981. Natural and man-made radiocarbon as a tracer for coastal upwelling processes. In: Richards FA, editor. Coastal Upwelling. Washington DC: American Geophysical Union. p 298-302.

Stuiver M, Braziunas TF. 1993. Modeling atmospheric ${ }^{14} \mathrm{C}$ influences and ${ }^{14} \mathrm{C}$ ages of marine samples to 10,000 BC. Radiocarbon 35(1):137-89.

Stuiver M, Reimer PJ. 1993. Extended ${ }^{14} \mathrm{C}$ data base and revised Calib $3.0{ }^{14} \mathrm{C}$ age calibration program. Radiocarbon 35:215-30.

Stuiver M, Reimer PJ, Braziunas TF. 1998. High-precision radiocarbon age calibration for terrestrial and marine samples. Radiocarbon 40(3):1127-51.

Suess HE. 1955. Radiocarbon concentration in modern wood. Science 122:415-41. 